\title{
Comparative Anatomy of Labyrinth and Gill of Catfish (Clarias gariepinus) (Burchell, 1822) and Snakehead Fish (Channa striata) (Bloch, 1793)
}

\author{
Ina Karlina ${ }^{1, *}$, Muhammad Ja'far Luthfi ${ }^{2}$ \\ ${ }^{1}$ Center for Integrative Zoology, ${ }^{2}$ Biological Education Department, Faculty of Science and Technology, UIN Sunan Kalijaga \\ Jl. Marsda Adisucipto, No. 1 Yogyakarta 55281, Tel. +62-274-540971, Fax. +62-274-519739, Indonesia. \\ Author correspondency*: \\ Ikarlina017@gmail.com
}

\begin{abstract}
Dumbo catfish (Clarias gariepinus) and Gabus (Channa striata) have additional organ respiratory system structures in the gills, called labyrinth. This organ is a tool for fish to take oxygen directly from the air so that it can live in low oxygen habitats. Both fish have differences at the Order level. Catfish is an order of Siluriformes as Gabus is an order of Perciformes. The purpose of this study was to distinguish the anatomy and histology of the gill structure and labyrinth in both fish. The macroanatomy observation was conveyed by dissection to determine the gill topography in the two fish species. Histology preparations were carried out using the paraffin method and using Hematoxylin-Eosin (HE) staining that showed in the labyrinth organ there were many blood vessels to bind oxygen then distributed to all parts of the fish's body.
\end{abstract}

Keywords: Anatomy; Catfish (Clarias gariepinus); Snakehead fish (Channa striata); Hematoxylin-Eosin (HE); Histology; Labyrinth

\section{INTRODUCTION}

Catfish (Clarias gariepinus) and Snakehead Fish (Channa striata) have an additional structure in their gill organs but both were grouped into different orders. Catfish belonging to order Siluriformes while Snakehead Fish belonging to order Perciformes. Labyrinth is a multiplied membrane that filled with blood capillaries located at the top of second and thirdgill arches, and organ shaped like a sponge. Fujaya (2008) stated that some species of fish have a labyrinth which is an upward expansion of gills forming folds and so become irregular cavities. Explanation other sources that gills of catfish have a small size that located on the back head (Najiyati, 2010 in Utomo 2006). According to Jayaram, 1981 (in Utomo, 2006) this size causes catfish had trouble to filter water in, therefore catfish need a labyrinth as an additional respiration tool.

The labyrinth allowed catfish and Snakehead Fish to extract oxygen directly from the air so they can live in low content oxygen waters (Susanto, 1989; Angka et al., 1990; Suyanto, 1992). Insight into the development of organs in Pisces is still lack and limited (rather limited), so it required in-depth study to find out more extensively (Fumio \& Takashi, University of Tokyo, 2010). Based on the facts it is necessary to have a more in-depth study about labyrinth structure in gills of catfish and Snakehead Fish. This confirmed that groupings of Pisces members are generally not only based on morphological features and characteristics but also anatomy and histology aspects that interesting to be studied further. Not only to refer to those additional structures in helping and sustain its life-related adaptation aspects to the environment, but also the study of anatomy and histology.

\section{METHOD}

This study used three adults Catfish (Clarias gariepinus) and Snakehead Fish (Channa striata). The anatomical observation was done by observing the color, shape, and length of the gill and labyrinth-gill. Histological slides used paraffin method and stained with using Hematoxylin-Eosin (HE).

\section{RESULTS AND DISCUSSION}

Gill and Labyrinth-gill Anatomy of Adult Catfish (Clarias gariepinus) and Snakehead Fish (Channa striata)

Based on the results obtained from the study gill color on catfish and bright red bright Snakehead Fish, this indicates the number of blood vessels capillaries and blood cells contained inside. Gills of catfish and Snakehead Fish consist four pairs of sheets, while the shape is like a raker, besides it has three main structures namely gill arch, gill racker and gill filament. Gills catfish and Snakehead Fish are located on the side-head 
precisely on right and left of the pharynx and outside covered by an operculum. Gill arch or branchialis archus structure in catfish and Snakehead Fish are colored white is a place of attachment gill filament and filament. The differences between catfish are the gills surface which smaller and narrower than Snakehead Fish which wider.

\section{- Gill}
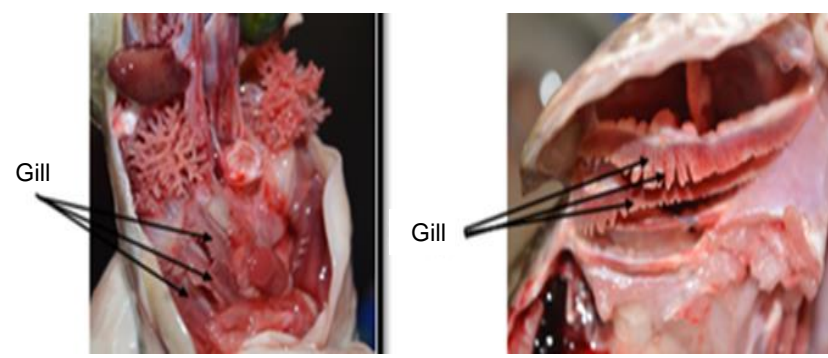

Figure 1. Catfish gill and Snakehead Fish.

Gill filament or hemibranchia in catfish and Snakehead Fish resembles a raker and attaches on gill arch. Each gill sheet consists of pair filaments, and on each filament contains many thin layers called lamela. Lagler et al (1997) stated that gills consist of pair gill filaments, each filament consists of thin transverse fiber covered by a thin epithelium called lamella. The lamella is a filament composer. Another structure is the gill or gill rakers, which is a pair of rows cartilage rods are short and serrated small, attached to the front of gill arch and has a function to filter the water respiration. According to Achmad (2005), gills on the anterior middle edge are equipped with a structure (gill rakers) that function filtering particles.
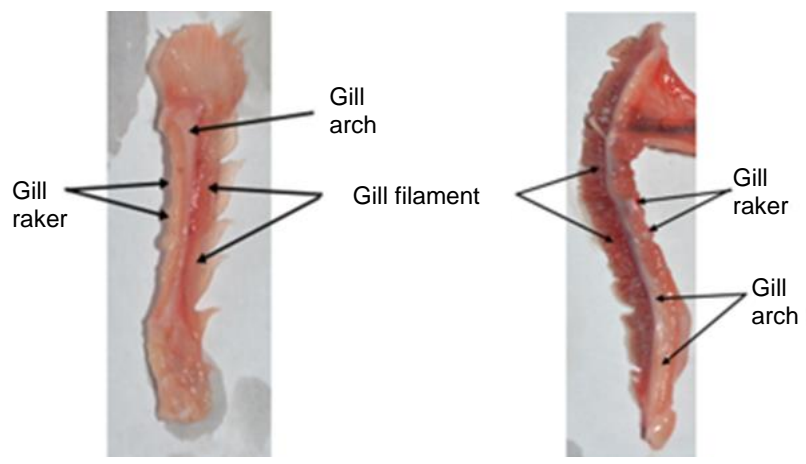

Figure 2. Portions of Catfish and Snakehead Fish gill.

\section{- Labyrinth-gill}

The results from the research, the labyrinth on the catfish has bright-pink color, while Snakehead Fish has reddish cream color. The pink color is caused by capillary blood vessels, which are not much different from gills. Catfish labyrinth has sponge-like shaped (arborescent) with irregular structures. This signifies many structures resembling vesicle gas as air reserves that support respiratory process, especially when lacking oxygen. While snakehead Fish labyrinth has solid-shape with a serrated edge. Labyrinth is located on the first-gill sheets catfish and the longest sheet attached to the edges. According to Kisia (2010), the labyrinth in clarias cluster gills is covered by respiratory epithelial folds and derived from the first-gills of the dorsolateral head bone of gill cover. While labyrinth of Snakehead Fish is located lies in the pharyngeal. According to Sukiya (2010), the labyrinth of Snakehead Fish is a development in dorsal part a pair of the pharynx and an extension known as suprapharyngeal space, this room is supported when in lack oxygen and the process breathes.

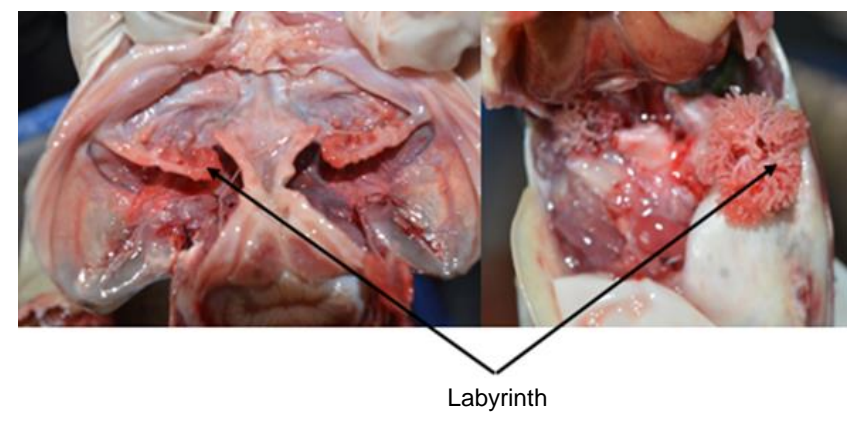

Figure 3. Catfish and Snakehead Fish Labyrinth-gill.

Macroanatomically, the gills structure of catfish and Snakehead Fish are generally same, they have three main parts i.e gill raker, gill arch, and gill filament. These three structures have the same functions. A form of gill raker dumbo catfish serrated small dense and tightly neat, while the form of gill raker Snakehead Fish is larger, uneven and irregular. The striking difference is shown in terms of color, structure, and location or topography of the labyrinth. All anabantoid/anabyroid species have specialized labyrinth organs to support gas exchange and involved in the surface water respiratory behavior (Graham, 1997).

Reviewing in terms of complexity, resilience and the surface area catfish has more survive than Snakehead Fish. The more complex and larger surface area of the respiratory tool structure then accommodated oxygen reserve will more plenty. So that fish can survive longer when lack oxygen in the water. According to Kisia (2008), catfish can survive in last minutes or even several hours because it has an additional respiratory tool called arboresence, this tool is a folded membrane which is full of blood capillaries located in the upper cavity above the gills.

\section{Histology of Gill and Labyrinth-gill}

\section{- Gill}

Results showed that catfish and Snakehead Fish gills have a thin epithelial layer for the efficiency of oxygen and gas exchange (absorption and release). In addition, gills have a function to regulate salt and water exchange and function in excretion of nitrogenous waste products, 
especially ammonia. Gill is composed by gill raker, gill arch and gill filament. This gill arch composed by primary lamella that has the parallel lamella secondary sheets along primary lamella. This secondary lamella functions to take oxygen from water. Histologically, primary lamella is composed of pillar cells lined up and cells are covered in a thin epidermal membrane semipermeable. Spaces between pillar cells are called lacuna as the blood pass-over place.

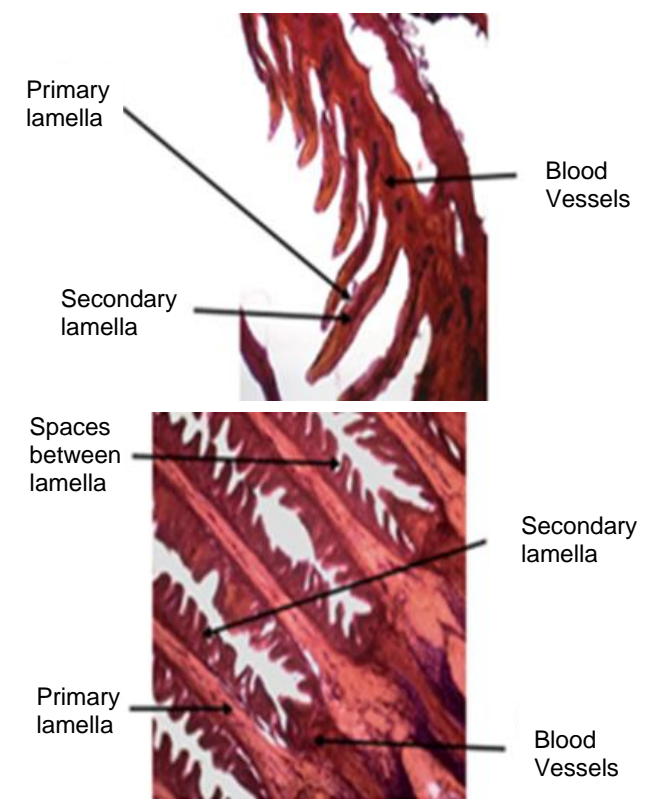

Figure 4. Gill of Catfish and Snakehead Fish (40x10 magnification). Hematoxylin-Eosin (HE).

According to Lagler et al (1997), lamella is composed of thin epidermal cells and stem-shaped support cells (pillar cells) that helps blood-flow to the gills. The thickness of lamella are varied depends on species and its activity. Gas exchange occurs in secondary lamella which is the fold of epithelial cells with a single supports cell layer and separated by pillar cells. A thin layer of blood vessels lies between the pillar cells and epidermis which is become gas exchange site, nitrogenous wastes of metabolites remains and some electrolyte exchanges. Pseudobrankhia is located at the bottom of the upper operculum. This organ is a gill arch with a series of filaments. The function of pseudobranchial is not yet known, but it is thought the structure that supplies oxygen-rich blood to chloroid cells optical and retinal, it may play a role in baroreceptor and thermoregulation functions. In addition, gills are equipped with a number of glands known as the branchial gland i.e specialized gill epithelial cells. These glands are a mucous gland and the acidophilic glands (chloride cells).

Marrison (2007 in Prasetyo, 2011), stated that the gill arch consists of the primary lamella. Each primary lamella has a secondary lamella located in a perpendicular to the primary lamella. Gill arch is covered by epidermal tissue and contained many mucosal cells. In the primary lamella, contained chloride cells that commonly found in basal (proximal) of lamellae. These cells function in ion transport and detoxification. Gas exchange occurs throughout the surface of secondary lamella primarily through the exchange of blood and water coming from the environment. The secondary lamellar surface consists by squamous cell epithelial overlap, usually, one layer supported and separated by pillar cells.

\section{- Labyrinth}

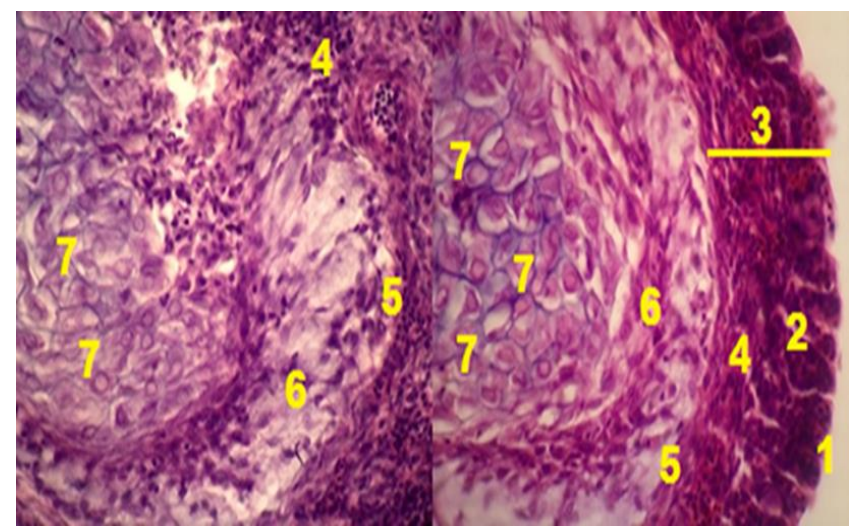

Figure 6. Histology of labyrinth-gill of Catfish (Clarias gariepinus). HE staining. (40x10 magnification). 1. Microvili, 2. Goblet cell, 3. Epithelium cell, 4. Granula, 5. Lamina basal, 6. Loose connective tissue, 7. Capillary blood vessels.

The outer surface covered by epithelial cells and restrict two internal parts as almost all layers of the body or the organs are covered epithelial cells. Epithelial cells construct the labyrinth of dumbo catfish that very dense and almost no intercellular space. Flat-shaped and belonging to a simple squamous cell type epithelium, mostly in the respiratory organs that have primary functions to exchange substances. According to Orphans (1996), in some types of epithelium form a bulge or crease to expand its surface area.

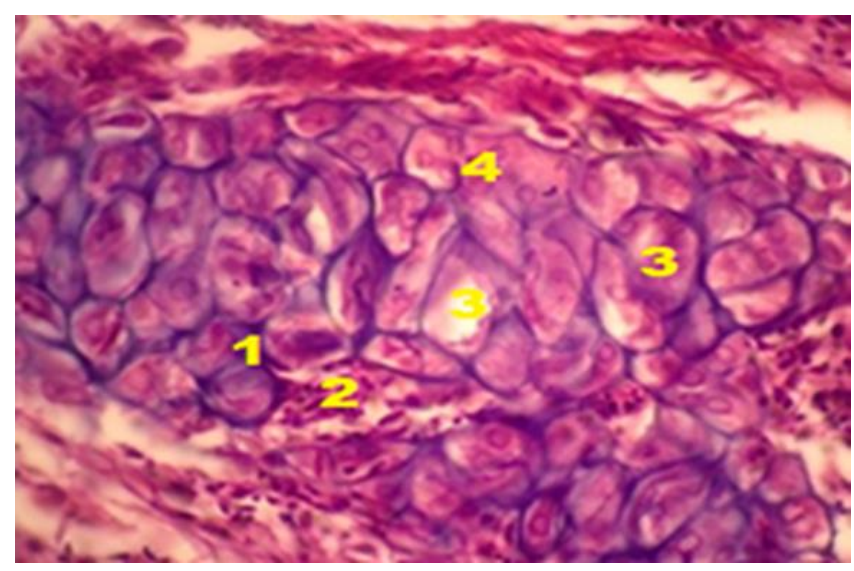

Figure 7. Histology of labyrinth-gill of Dumbo catfish (Clarias gariepinus). HE staining. (40x10 magnification). 1. Intercapillary space, 2. Perisite (Pervascular cells), 3. Capillary blood, 4. Endotel. 
The surface epithelial type of labyrinth catfish is simple squamous epithelial cells. These cells consist of a single layer of epithelial cells as the point of contact for the epithelial tissue with the basement membrane. Types can be in face rapid diffusions areas such as lung alveoli lining (respiratory unit called airbags), endothelium (blood vessel lining), capillaries, kidneys, the main body cavity (mesothelium), and other major areas where the little activity occurred. The respiratory mucosa is composed of epithelial cells and there is a lamina propria. The epithelium is a tall columnar with cilia and goblet cells. Supporters of lamina propria under the epithelium contain elastin. The function of simple squamous epithelial cells is responsible for allowing the exchange of oxygen. They are also responsible for blood filtering, and diffusion that allows passing oxygen in the blood. In addition, there is also a connective tissue that connects with the network under it, the type of loose connective tissue which is the most widely spread connective tissue in the body of vertebrate animals. Histological description showed that labyrinth of dumbo catfish has a loose connective tissue which is a network of rare cells. Part of tissue composed of a matrix which located beneath the matrix epithelial layer of mucous fluid, the deepest part which is capillary blood vessels. This capillary vessel is limited by endothelial cells that are flattened, located long in accordance with the blood flow, are blue and prominent into the lumen.

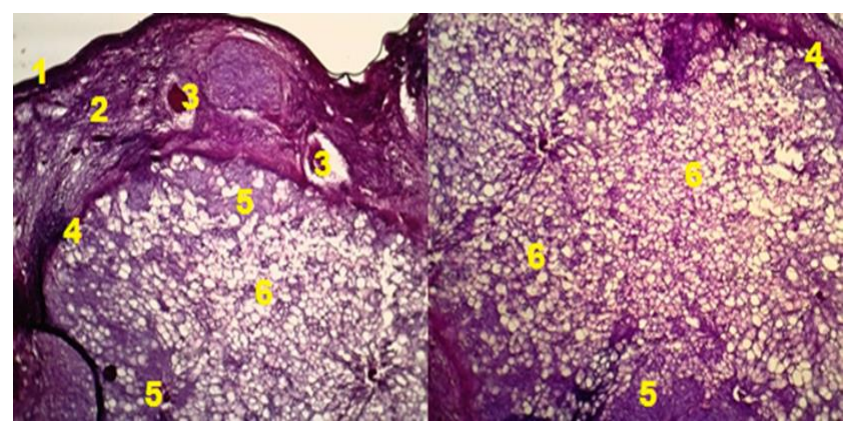

Figure 8. Histology of labyrinth-gill of Gabus (Channa striata). HE staining. (10x10 magnification). 1. Microvilli, 2. Epithelium layer, 3. Goblet cell, 4. Lamina basal, 5. Connective tissue, 6. Capillary blood vessel.

Labyrinth in Snakehead Fish is known diverticula although it functions equally with the labyrinth in catfish as an additional tool when fish is in lack oxygen. Diverticula is in the oral cavity and pharynx. Diverticula is in a group of Snakehead fish (channa). According to John, Karl and Robert (1997), diverticula is coated by respiratory epithelium with a numerous blood supply, usually from afferent gill circulation. This showed that the coating and composition of the constituent are same as the labyrinth in dumbo catfish. Figure 8, showed the tissue and constituent cells of the Snakehead Fish labyrinth, the outermost part of respiratory epithelial cells and blood vessels. There is a type of respiratory epithelium and also equipped with microvilli, which functions from microvilli to exchange and absorb substances. There is a goblet cell that serves to convert mucus into latex/gum and equipped by basal lamina at the base-part.

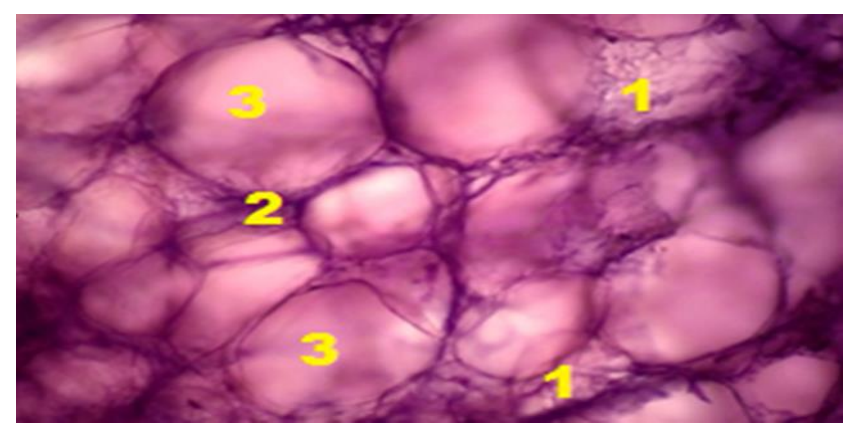

Figure 9. Histology of labyrinth-gill of Snakehead Fish (Channa striata) HE staining. (10x10 magnification). 1. Loose connective tissue, 2. Tight connective tissue and, 3. Blood vessel.

Lamina basal as a barrier between epithelial tissue with underlying tissue, the deepest part of connective tissue and capillary blood vessels. Seen on the histology of labyrinth Snakehead Fish there is connective tissue that connects with other parts. Although catfish and Snakehead Fish have additional breathing apparatus, it can be seen from the development of aspect and different surface area, the endurance if compared between them is different. Seen on the histologic picture both in dumbo catfish is more complex than Snakehead Fish. Labyrinth of catfish has a mucous-stratified epithelium, whereas Snakehead Fish has a pseudostratified epithelium. The difference is striking shown at 40 times magnification, the tissue quite clears constituent cells and their shape. In the labyrinth of Snakehead Fish, the surface area is not as wide as in catfish. Reviewing from the aspects, the surface area and structure cell and its constituent tissue on catfish are more complex than Snakehead Fish.

\section{Measurement Morphometric of Gill and Labyrinth}

Table 1. Calculation Standard Deviation of Gill and Labyrinth.

\begin{tabular}{clll}
\hline \multirow{2}{*}{ No } & Measured Aspects & \multicolumn{2}{c}{ Standard Deviation Value } \\
\cline { 3 - 4 } & & Catfish & Snakehead Fish \\
\hline 1 & Mass Left gill (gram) & $5,01 \pm 0,004$ & $17,83 \pm 0,55$ \\
2 & Mass Right gill $(\mathrm{gram})$ & $5,34 \pm 0,045$ & $17,74 \pm 0,55$ \\
3 & Filament Length 1 $(\mathrm{cm})$ & $4,07 \pm 0,002$ & $4,83 \pm 0$ \\
4 & Filament Length 2 $(\mathrm{cm})$ & $3,84 \pm 0$ & $4,68 \pm 0,004$ \\
5 & Filament Length 3 $(\mathrm{cm})$ & $2,90 \pm 0$ & $2,89 \pm 0$ \\
6 & Filament Length 4 $(\mathrm{cm})$ & $1,97 \pm 0$ & $2,43 \pm 0$ \\
7 & Gill Arch Length 1 $(\mathrm{cm})$ & $15,56 \pm 0,08$ & $32,24 \pm 0$ \\
8 & Gill Arch Length 2 $(\mathrm{cm})$ & $13,67 \pm 0,01$ & $26,18 \pm 0,004$ \\
9 & Gill Arch Length 3 $(\mathrm{cm})$ & $11,80 \pm 0,01$ & $12,75 \pm 0$ \\
10 & Gill Arch Length 4 $(\mathrm{cm})$ & $10,08 \pm 0,002$ & $11,58 \pm 0$ \\
11 & Mass labyrinth $(\mathrm{gram})$ & $3,81 \pm 0$ & $2,44 \pm 0$ \\
\hline
\end{tabular}


Measured aspects include mass and length of fish, right and left labyrinth mass, the overall of labyrinth and gills mass, the right and left labyrinth mass, the right and left gills of each gill sheet, and length of filament gill and gill arch. This study focused on gill and labyrinth comparisons. So the standard deviation calculation is more focused on calculation aspects of the left and right gill morphology, right and left labyrinth volume, long morphometry of filament and gill arch.

Value of standard deviation that was measured on calculation gill mass in catfish was 0.004 and 0,045 on right gill. While on the left and right gills of Snakehead Fish were 0,55. Measuring the mass of labyrinth catfish and Snakehead Fish is 0. Morphometry length of four filament gill in catfish is 0 , whereas in Snakehead Fish is 0 and measurement on the four-gill arch length of catfish is $0.08,0.01,0.01$ and 0.002 while in the Snakehead Fish is 0. Data was indicated that the diversity of samples under study is small, the smaller standard deviation values obtained indicate that the sample is same. Mass between left and right gill is same, it is seen from the mass of the two is similar to maintain balance. Based on the morphometric data showed that the smaller standard deviation calculation value, the sample diversity is small, meaning sample used in this study is the same. Length of each gill sheet is also different. It is seen from the development of labyrinth in catfish is more developed than Snakehead Fish.

\section{CONCLUSION}

Gills of catfish and snakehead fish are bright-red color, four-gill sheets with three main structures: gill arch, raker, and filament, located on side of the head and protected by an operculum. Catfish labyrinth has a pink color, shaped like a sponge, attached to the first gill, solid in shape with jagged edges, located near the pharynx. Catfish and snakehead fish gills consist of primary lamella, secondary lamella, inter-lamella, blood vessels, epithelial cells, and pole cells. Catfish labyrinth has microvilli, goblet cells, epithelium lining, granules, basal lamina, loose connective tissue, capillaries, perivascular and endothelium, whereas in snakeheadfish there are microvilli, epithelium lining, goblet cells, basal laminae, connective tissue, and capillary blood vessels.

\section{REFERENCES}

Achmad dkk, 2005. Struktur hewan. Universitas terbuka. Jakarta. Fujaya, 2008. Fisiologi ikan. PT Rineka Cipta, Jakarta.

Fumio \& Takashi, 2010, Histology of fish. University of Tokyo. Tokyo Press.

John E. Bardach, Lagler, dan Miller, 1997. Ichtyology. University of Michigan. Wiley Internasional publisher. USA.

Kisia, Seth M, 2010. Structures and funtions. Markono Print Media Pte Ltd, USA an imprint of Edenbrige Ltd., British Channel Island.

Prasetyo, 2011. Proses pernafasan pada ikan. Jurnal Sistem Regulasi pada Hewan Perairan. Diunduh dari web $\mathrm{http} / / \mathrm{www}$.sistem.regulasi.hewan.perairan. Accessed on a date March 20th 2015, at 05.30 WIB

Sukiya, 2003. Biologi Vertebrata. Universitas Negeri Yogyakarta: JICA

Susanto, 1989; Murhananto, 2002. Jenis perairan sesuai ikan lele. Diunduh dari web http///www.perairan.ikan.lele.com. Accessed on a date April 11th 2015, at 13:45 WIB.

Suyanto, 1986. Suyanto, S.R., 2003. Ikan. Penebar Swadaya. Jakarta

Utomo 2006. Letak dan morfometri insang pada ikan lele. Jurnal Penelitian Insang Ikan. Diunduh dari web http//www.insang.ikan.lele.com. Accessed on a date March 12th 2015, at 10:00 WIB.

Wildan yatim, 1996. Biologi Modern Histologi. Tarsito Bandung, Anggota IKAPI: Bandung. 